\title{
Ungkapan Kamiran-J Retak Permukaan pada Bar Silinder Padu Kenaan Beban Ragam I
}

\author{
Al Emran Ismaila*, Ahmad Kamal Ariffin ${ }^{b}$, Shahrum Abdullah ${ }^{b}$, Maryam Jameelah Ghazalib \\ ${ }^{a}$ Fakulti Kejuruteraan Mekanikal dan Pembuatan, Universiti Tun Hussein Onn Malaysia, Batu Pahat 86400 Johor, Malaysia \\ bJabatan Kejuruteraan Mekanik dan Bahan, Fakulti Kejuruteraan, Universiti Kebangsaan Malaysia 83600 Bangi, Selangor, Malaysia
}

*Corresponding author: emran@uthm.edu.my

\section{Article history}

Received :25 April 2013

Received in revised form :

21 May 2013

Accepted :15 March 2014

Graphical abstract

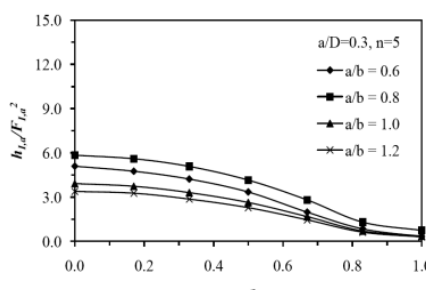

$$
\begin{aligned}
& \frac{J\left(\frac{x}{h}\right)}{J_{e}\left(\frac{x}{h}\right)}=1+\frac{2 \alpha\left(\frac{\sigma_{a}}{\sigma_{o}}\right)^{n-1}}{\pi\left(\frac{a}{R}\right)\left(1-v^{2}\right)}\left(\frac{h_{I, a}\left(\frac{x}{h}\right)}{F_{I, a}^{2}\left(\frac{x}{h}\right)}\right) \\
& \frac{J\left(\frac{x}{h}\right)}{J_{e}\left(\frac{x}{h}\right)}=1+\frac{9 \pi \alpha\left(\frac{3 \pi}{16} \frac{\sigma_{b}}{\sigma_{o}}\right)^{n-1}}{128\left(\frac{a}{R}\right)\left(1-v^{2}\right)}\left(\frac{h_{I, b}\left(\frac{x}{h}\right)}{F_{I, b}^{2}\left(\frac{x}{h}\right)}\right)
\end{aligned}
$$

\begin{abstract}
In this study, J-integral expression for surface crack in solid cylindrical bars subjected to mode I loadings were developed and analysed. These expressions were used to predict J-integral along the crack front for semi-elliptical crack shaped which different in sizes and geometries. One of the advantages of these expression were to accelerate any large deformation analysis generally which takes longer computational time. Finite element analysis was used to determine a fully plastic parameter called $h$-function. There were two types of mode I loading used in this work namely tensile force and bending moment. Results found that J-integral predictions were succesfully conducted. However, the predictions were dependent on the crack parameters used. Increasing the crack depth, J-integral prediction required different limit load for different position along the crack front. For the case of shallow cracks, J-integral determinations can be implemented succesfully except for the case of position in the vicinity of the outer points.
\end{abstract}

Keywords: J-integral; surface crack; mode I; limit load

Abstrak

Dalam kajian ini, ungkapan kamiran-J bagi retak permukaan pada bar silinder padu kenaan beban ragam I dibangunkan dan dianalisis. Ungkapan ini digunakan untuk meramal kamiran-J di sepanjang retak depan bagi retak berbentuk semi-elips yang berlainan saiz dan geometri. Di antara kelebihan ungkapan ini adalah ia dapat mempercepatkan analisis yang melibatkan ubah bentuk plastik yang pada umumnya mengambil masa yang agak lama. Analisis unsur terhingga digunakan untuk menentukan satu parameter plastik sepenuhnya yang dipanggil sebagai fungsi- $h$. Terdapat dua jenis beban ragam I yang digunakan iaitu daya tegangan dan momen lentur. Daripada keputusan didapati ramalan kamiran-J berjaya dijalankan. Walau bagaimanapun, ramalan tersebut adalah bergantung kepada parameter retak yang digunakan. Dengan meningkatkan kedalaman sesuatu retak, peramalan kamiran-J memerlukan had beban yang berlainan untuk kedudukan yang berlainan. Bagi kes kedalaman retak yang cetek, penentuan kamiran-J boleh dijalankan dengan jayanya kecuali pada kedudukan di sekitar titik terluar.

Kata kunci: Kamiran-J; retak permukaan; ragam I; had beban

C) 2014 Penerbit UTM Press. All rights reserved.

\subsection{PENGENALAN}

Bar berbentuk silinder padu banyak digunakan dalam bidang kejuruteraan untuk proses pemindahan kuasa daripada satu komponen kepada komponen yang lain. Selain daripada bar jenis ini, bar yang berbentuk silinder berlubang juga banyak digunakan untuk tujuan yang sama. Kegagalan sesuatu bahan atau komponen boleh dibahagikan kepada tiga peringkat yang utama iaitu: permulaan retak mikro, perambatan retak dan kegagalan struktur. Secara umumnya, pendekatan mekanik patah digunakan untuk menganalisis kelakuan retak berkenaan. Untuk bahan yang diandaikan anjal-lelurus adalah memadai untuk menggunakan faktor keamatan tegasan (SIF) dalam menganalisis retak. Jika kesan keplastikan bahan menjadi ketara, kamiran- $J$ perlu digunakan untuk tujuan tersebut. Terdapat banyak penyelesaian terhadap SIF yang boleh didapati daripada Murakami \& Tsuru ${ }^{1}$. Walau bagaimanapun, ia amat terhad kepada masalah duadimensi dan pada kedudukkan tertentu sahaja. Keadaan yang sama juga dapat diperhatikan terhadap penyelesaian kamiran- $J$ terutama dalam keadaan bahan bersifat anjal-plastik.

Pendekatan yang berlainan pula perlu digunakan untuk menganalisis bahan yang mulur. Penggunaan SIF untuk menyelesaikan masalah ini tidak sah kerana kesan keplastikan bahan tidak diambil kira dalam pengiraan SIF. Oleh itu, kamiran- $J$ diperkenalkan untuk menganalisis keadaan berkenaan. Kelakuan kamiran- $J$ terhadap bar silinder padu masih perlu diberikan perhatian yang mana penyelesaian terhadap kamiran- $J$ sangat kurang berbanding dengan $\mathrm{SIF}^{2}$. Ini adalah mungkin kerana masa 
komputasi untuk menyelesaikan masalah ini secara relatifnya adalah lebih lama berbanding dengan penyelesaian secara anjal.

Untuk menjadikan analisis kamiran- $J$ menjadi lebih praktikal kepada jurutera, kaedah penganggaran kamiran- $J$ hendaklah diberikan perhatian dan dibangunkan. Dalam menjalankan proses penganggaran ini, had beban untuk geometri retak tertentu diperlukan yang mana ia digabungkan dengan kaedah pendekatan tegasan rujukan ${ }^{3}$. Kaedah ini menawarkan cara yang mudah untuk mengenal pasti kawasan-kawasan yang mengalami tegasan yang genting dalam sesuatu komponen mekanikal. Ia adalah satu pendekatan yang lebih intuitif dan kurang sensitif terhadap sifatsifat mekanik bahan. Kelebihan penggunaan pendekatan ini ialah ia tidak memerlukan perincian kelakuan tegasan dan terikan sesuatu bahan dengan lengkap. Lei $^{4}$ memberikan perincian terhadap had beban silinder berlubang dan plat. Walau bagaimanapun, penyelesaian had beban terhadap silinder padu kenaan beban tunggal atau tergabung sukar untuk didapati kerana kurang kajian yang dijalankan terhadapnya.

Bahan yang bersifat anjal-plastik akan menghasilkan kesan keplastikan yang ketara bila dikenakan beban yang tinggi. Maka, kamiran- $J$ digunakan untuk menganalisis keadaan tersebut. Terdapat banyak analisis kamiran- $J$ yang dijalankan terutamanya plat $^{5}$ dan rod berongga atau paip ${ }^{6}$, tetapi analisis yang melibatkan bar silinder padu amat jarang didapati dan terhad kepada beberapa bentuk dan geometri retak yang tertentu sahaja ${ }^{2}$. Kelakuan retak permukaan pada rod silinder padu dengan menggunakan kamiran$J$ masih lagi dalam peringkat penyelidikan termasuklah yang dikenakan beban ragam I, III dan gabungannya ${ }^{7,8}$.

Perkara utama yang menyebabkan kekurangan kajian tersebut ialah kesukaran untuk memodelkan retak tiga-dimensi. Ia juga memerlukan model matematik yang tinggi dan masa yang panjang diambil untuk menyelesaikan masalah retak dengan menggunakan analisis anjal-plastik. Disebabkan masalah ini, kaedah penganggaran kamiran- $J$ hendaklah dibangunkan untuk mempercepatkan analisis tersebut. Terdapat, dua kaedah yang digunapakai dalam proses penganggaran tersebut iaitu pendekatan tegasan rujukan ${ }^{9}$ dan kaedah Institut Penyelidikan Kuasa Elektrik $(E P R I)^{10}$. Walau bagaimanapun, pendekatan tegasan rujukan digunakan kerana ia tidak memerlukan perincian terhadap kelakuan tegasan dan terikan sesuatu bahan. Tetapi masalah utama pengunaan pendekatan yang pertama ialah penggunaan had beban untuk sesuatu geometri retak.

Pada masa kini tidak terdapat had beban tergabung yang boleh didapati untuk bar silinder padu terutama sekali bagi beban tergabung. Oleh itu, ia perlu dibangunkan dan digabungkan dengan pendekatan tegasan rujukan untuk proses penganggaran kamiran- $J$ ini. Dalam penyelidikan ini, analisis terhadap kelakuan retak permukaan pada bar silinder padu dijalankan. Bentuk dan geometri retak yang berkaitan dipertimbangkan dan dianalisis dengan menggunakan pendekatan mekanik patah. Serta membangunkan dan menilai had beban tunggal dan tergabung pada bar silinder padu yang mengandungi retak dan mengkaji hubungan di antara kamiran- $J$ dan had beban untuk bar berbentuk silinder padu yang mengandungi retak.

\subsection{ANGGARAN KAMIRAN-J}

Kamiran- $J$ pertama kali diperkenalkan oleh Rice ${ }^{11}$. Dengan mengandaikan retak pada plat dua-dimensi sama ada anjal atau anjal plastik, kamiran- $J$ ditakrifkan sebagai satu lengkungan di sekeliling retak. Ia dinilai dalam arah lawan jam seperti dalam Rajah 1.0 yang bermula pada muka retak bawah yang melalui lengkungan $\Gamma$ ke muka retak atas. Kamiran- $J$ diberikan seperti berikut
$J=\int_{\Gamma}\left(W d y-\vec{T} \cdot \frac{\partial u}{\partial z} d s\right)$

yang mana, $\vec{T}$ ialah vektor tarikan yang ditakrifkan normalan keluar di sepanjang $\Gamma, T_{i}=\sigma_{i j} n_{i}$ atau pun daya per unit panjang, $u$ adalah vektor anjakan dan $d s$ ialah satu unsur pada lengkungan $\Gamma$.

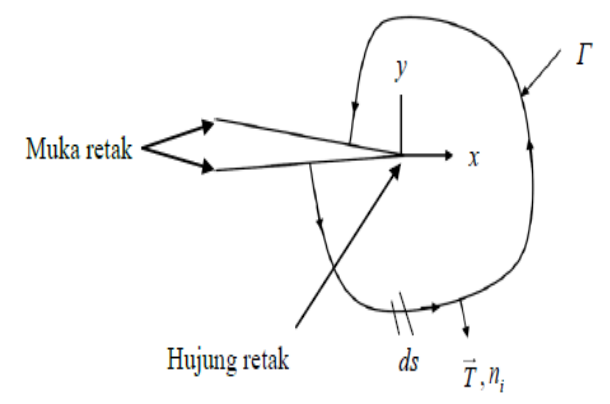

Rajah 1.0 Takrifan kontur untuk penilaian kamiran- $J$

Manakala, $W$ ialah ketumpatan tenaga terikan seperti berikut

$W=\int_{0}^{\varepsilon} \sigma_{i j} d \varepsilon_{i j}=\int_{0}^{\varepsilon}\{\sigma\}^{T} d\{\varepsilon\}$

yang mana, $\varepsilon_{i j}$ ialah terikan tensor dan $\{\varepsilon\}$ mewakili vektor terikan. Ciri-ciri ketidakbergantungan laluan terhadap kamiran- $J$ seperti Persamaan (1) telah dibuktikan dalam dalam Rice [11] dengan mengaplikasikan theorem Green untuk mana-mana lengkungan tertutup $\Gamma^{*}$ seperti berikut

$\int_{\Gamma^{*}}\left(W d y-\vec{T} \cdot \frac{\partial u}{\partial z} d s\right)=0$

Penggunaan konsep faktor keamatan tegasan (SIF) adalah terbatas hanya dalam ruang lingkup analisis anjal sahaja. Penggunaan SIF amat berjaya dalam menjalankan analisis anjal ke atas bahan yang berkekuatan tinggi dan berkeliatan yang rendah. Tetapi ia amat terbatas ke atas bahan yang mulur yang melibatkan skala plastik yang tertentu. Oleh yang demikian, ia tidak boleh digunakan untuk analisis yang melibatkan kesan keplastikan yang ketara. SIF atau $K$ boleh ditukar kepada kamiran- $J$ dengan mudah jika bahan yang digunakan adalah anjal seperti berikut ${ }^{12}$

$J_{e}=\frac{K_{I}^{2}}{E}\left(1-v^{2}\right)$

yang mana, $J_{e}$ ialah kamiran- $J$ anjal dan $K$ ialah faktor keamatan tegasan. Manakala, anggaran kamiran- $J$ untuk analisis anjalplastik adalah hasil tambah kamiran- $J$ anjal, $J_{e}$ dan kamiran- $J$ plastik, $J_{p}$ seperti berikut ${ }^{13}$

$J=J_{e}+J_{p}$

Dalam Persamaan (5), $J_{e}$ ditakrifkan seperti Persamaan (4), Manakala, $J_{p}$ ialah kamiran- $J$ plastik ${ }^{14}$ seperti berikut

$J_{p}=\alpha \varepsilon_{o} \sigma_{o} D h\left(\frac{N}{N_{L}}\right)^{n+1}$

yang mana, $\alpha$ dan $n$ adalah masing-masing pemalar bahan dan eksponen pengerasan terikan serta, $N$ ialah beban kenaan dan $N_{L}$ ialah beban penormalan bagi $N$ atau pun had beban. Manakala, $\varepsilon_{o}$ ialah terikan alah dan $\sigma_{o}$ ialah tegasan alah. Simbol $h$ pula ialah fungsi penentukuran plastik penuh dan dipanggil sebagai fungsi- $h$. Ia penting untuk menganggarkan kamiran- $J$ untuk bentuk dan 
geometri retak tertentu. Walau bagaimanapun, Lei ${ }^{15-17}$ menyatakan penyelesaian terhadap fungsi- $h$ masih lagi terhad dan banyak kajian perlu dijalankan untuk tujuan tersebut.

\subsection{KAEDAH TEGASAN RUJUKAN}

Dalam kaedah tegasan rujukan ${ }^{18,19}$, kamiran- $J$ dianggarkan dengan menggunakan Persamaan (7) seperti di bawah

$$
\frac{J}{J_{e}}=\frac{E \varepsilon_{r e f}}{\sigma_{r e f}}+\frac{1}{2} \frac{L_{r}^{2} \sigma_{r e f}}{E \varepsilon_{r e f}}
$$

yang mana, $J$ ialah kamiran- $J$ keseluruhan, $J_{e}$ ialah kamiran- $J$ anjal, $L_{r}$ ialah penghampiran runtuhan plastik dan $E$ ialah modulus keanjalan. Tegasan rujukan, $\sigma_{r e f}$ dan terikan rujukan, $\varepsilon_{r e f}$ masingmasing boleh diberikan seperti berikut

$$
\begin{aligned}
& \sigma_{r e f}=\left(\frac{N}{N_{L}}\right) \sigma_{o} \\
& \varepsilon_{r e f}=\alpha \varepsilon_{o}\left(\frac{\sigma_{r e f}}{\sigma_{o}}\right)^{n}
\end{aligned}
$$

yang mana, $\sigma_{o}$ dan $\varepsilon_{o}$ adalah masing-masing tegasan dan terikan alah bagi sesuatu bahan. Beban yang dikenakan, $N$ dan $N_{L}$ ialah had beban atau beban pernormalan. Manakala, $L_{r}$ untuk beban tertentu ditakrifkan seperti ungkapan berikut

$$
\begin{aligned}
& L_{r}=\frac{\sigma_{r e f}}{\sigma_{0}}=\frac{P}{P_{L}} \\
& L_{r}=\frac{\sigma_{r e f}}{\sigma_{0}}=\frac{M}{M_{L}}
\end{aligned}
$$

yang mana, $P$ dan $M$ adalah masing-masing daya tegangan dan momen lentur yang dikenakan ke atas sesuatu komponen. Manakala, $P_{L}$ dan $M_{L}$ masing-masing adalah had beban daya tegangan dan had beban momen lentur.

\subsection{KAEDAH PENENTUAN HAD BEBAN}

Kaedah tegasan rujukan yang digunakan ini adalah untuk menganggarkan kamiran- $J$ di sepanjang retak depan untuk semua bentuk dan geometri retak. Dalam proses tersebut, had beban memainkan peranan yang penting. Had beban ialah satu parameter yang digunakan untuk mencirikan kelakuan plastik penuh yang mengandungi retak pada sesuatu struktur dan satu nilai had beban sahaja sepatutnya digunakan untuk mencirikan kepatahan mulur sesuatu bentuk struktur. Beban tunggal bagi daya tegangan, $P$ dan momen lentur, $M$ masing-masing diberikan seperti berikut 20

$$
\begin{aligned}
& P=\frac{\pi D^{2}}{4} \sigma_{a} \\
& M=\frac{\pi D^{3}}{32} \sigma_{b}
\end{aligned}
$$

yang mana, $D$ ialah garis pusat bar, $\sigma_{\mathrm{a}}$ ialah tegasan tegangan, $\sigma_{b}$ ialah tegasan lentur dan $\tau_{t}$ ialah tegasan ricih. Untuk model unsur terhingga tiga-dimensi kamiran- $J$ dan kamiran- $J_{e}$ anjal ditentukan pada titik-titik tertentu di sepanjang retak depan.

Manakala, $P_{L}$ dan $M_{L}$ masing-masing adalah had beban daya tegangan dan momen lentur. Ia juga adalah parameter setempat fungsi kepada kedudukkan titik di sepanjang retak depan. Dalam tatacara R6 $7,8,15$, parameter $L_{r}$ bukan sahaja digunakan untuk menggangarkan kamiran- $J$ malah ia juga digunakan sebagai ukuran penghampiran runtuh plastik. Had beban untuk penggangaran kamiran- $J$ kenaan beban tunggal adalah seperti berikut ${ }^{20}$

$$
\begin{aligned}
& P_{L}=\frac{\pi D^{2} \sigma_{o}}{4} \xi_{a}\left(\frac{a}{b}, \frac{a}{D}, \frac{x}{h}\right) \\
& M_{L}=\frac{D^{3} \sigma_{o}}{6} \xi_{b}\left(\frac{a}{b}, \frac{a}{D}, \frac{x}{h}\right)
\end{aligned}
$$

yang mana, $\xi_{a}$ ialah had beban daya tegangan ternormal dan $\xi_{b}$ ialah had beban momen lentur ternormal.

Manakala, $\sigma_{o}$ ialah tegasan alah normal dan $\tau_{o}$ ialah tegasan alah ricih. Gantikan Persamaan (12) dan Persamaan (14) ke dalam Persamaan (10), Persamaan (13) dan Persamaan (15) ke dalam Persamaan (11) masing-masing akan diberikan seperti berikut

$\xi_{a}\left(\frac{a}{b}, \frac{a}{D}, \frac{x}{h}\right)=\frac{\sigma_{a} / \sigma_{o}}{L_{r}}$

$\xi_{b}\left(\frac{a}{b}, \frac{a}{D}, \frac{x}{h}\right)=\frac{5}{3}\left(\frac{\sigma_{b} / \sigma_{o}}{L_{r}}\right)$

Selesaikan $L_{r}$ seperti dalam Persamaan (7), yang mana $J$ ialah kamiran- $J$ anjal-plastik yang didapati daripada analisis tak lelurus FEA sementara kamiran- $J$ anjal, $J_{e}$ boleh diperolehi daripada Persamaan (4). Ia hanyalah digunakan di sepanjang retak depan dan ia tidak boleh digunakan untuk menentukan kamiran- $J$ pada titik terluar pada retak depan kerana pada kedudukan tersebut, kamiran- $J$ adalah bermasalah dari segi ketunggalan. Satah terikan digunakan disebabkan di sepanjang retak ini mengalami kekangan bahan yang ketara. Masukkan $L_{r}$ masingmasing ke dalam Persamaan(16) dan Persamaan (17) untuk menentukan had beban ternormal, $\xi$.

\subsection{PEMODELAN RETAK}

Keratan rentas bar yang mengandungi retak adalah seperti Rajah 2.0. Dalam kajian ini garis pusat bar, $D=50 \mathrm{~mm}$ manakala panjang keseluruhan bar, $L=200 \mathrm{~mm}$. Nisbah bidang retak, $a / b$ dipilih dalam julat antara 0.0 hingga 1.2 dan kedalaman relatif retak, $a / D$ ialah di antara 0.1 hingga 0.6 . Bentuk dan geometri retak dipilih berdasarkan kepada pemerhatian mekanisma kegagalan lesu ${ }^{2}$. Modulus anjal, $E$ dan nisbah Poisson, $v$ yang digunakan untuk analisis anjal ini masing-masing ialah $222 \mathrm{GPa}$ dan 0.3.

Disebabkan analisis berbentuk simetri hanya melibatkan daya tegangan dan momen lentur, sukuan model unsur terhingga adalah memadai untuk tujuan tersebut. Ini adalah kerana dengan menggunakan model bersimetri, masa dan kos pengiraan untuk menyelesaikan sesuatu masalah dapat dikurangkan ${ }^{21}$. Dalam masa yang sama dapat meningkatkan ketepatan analisis. Pada hujung yang mengandungi retak, seluruh permukaan yang dikekang kecuali muka retak.

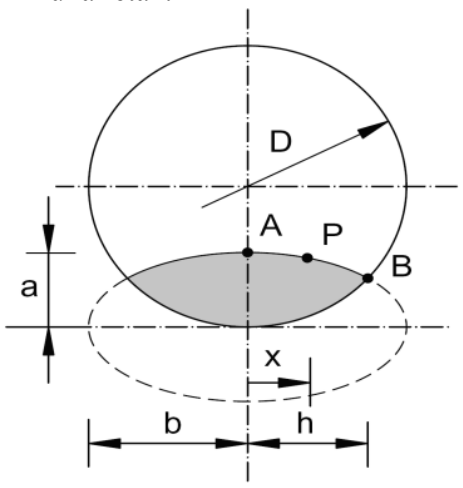

Rajah 2.0 Pencirian keratan rentas bar bulat sesatah dengan retak permukaan yang berbentuk semi-elips

Dalam menjalankan penyelakuan momen lentur adalah penting untuk membebankan bar tersebut secara jauh atau terasing iaitu 
beban tidak dikenakan secara terus kepada jasad unsur terhingga. Oleh itu, unsur rasuk tegar atau unsur MPC184 digunakan dengan menyambungkan unsur ini di sekeliling hujung tepi bar kepada satu titik yang tidak bersandar pada jasad itu seperti dalam Rajah 3.0. Momen lentur pada nod ini. Manakala, tegasan tegangan dikenakan secara terus pada keratan rentas di hujung bar ini.

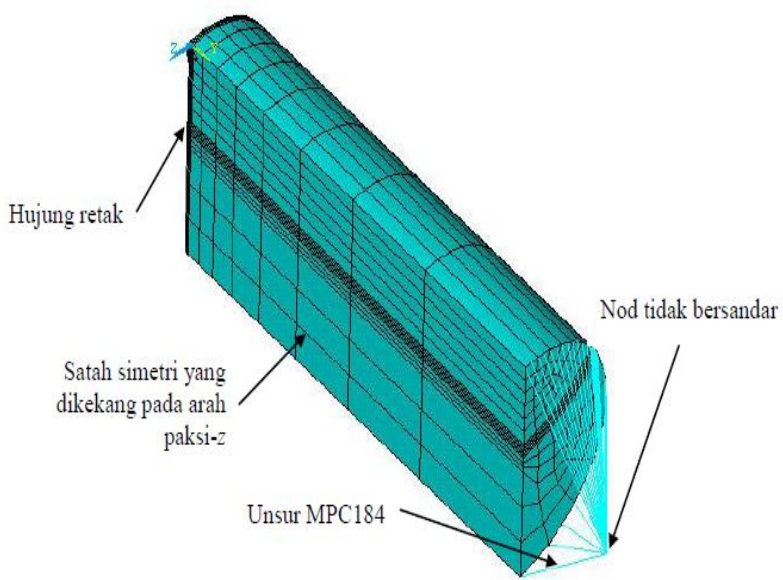

Rajah 3.0 Sukuan model unsur terhingga dengan unsur MPC184

Untuk proses pembebanan, pada hujung yang tiada unsur MPC185 model unsur terhingga ini dikekang. Manakala, momen lentur dikenakan pada nod yang tidak bersandar dan tegasan paksi dikenakan terus pada keratan rentas bar. Untuk memodelkan kelakuan plastik bahan, pengerasan isotropik berbilang lelurus (MISO) dipertimbangkan dan digabungkan dengan kriteria von Mises bersekutu dengan pengerasan isotropik dan aturan aliran. Ia digunakan untuk analisis terikan yang besar dan tidak sesuai untuk analisis berkitar yang tidak berkadaran. Persamaan (18) iaitu hubungan Ramberg-Osgood digunakan untuk menentukan nilai-nilai tegasan dan terikan terutamanya pada kawasan plastik seperti berikut [5]

$\frac{\varepsilon}{\varepsilon_{o}}=\frac{\sigma}{\sigma_{o}}+\alpha\left(\frac{\sigma}{\sigma_{o}}\right)^{n}$

yang mana, $\varepsilon_{0}$ ialah terikan alah, $\sigma_{o}$ ialah tegasan alah, $\alpha$ ialah pemalar bahan, dan $n$ ialah eksponen pengerasan terikan. Nilai $0.2 \%$ tegasan bukti digunakan untuk menentukan $\sigma_{o}$. Oleh itu, $\alpha=1$ digunakan untuk semua analisis tak lelurus. Dua jenis nilai $n$ yang digunakan iaitu 5 dan 10 untuk penyelakuan berangka 15-17. Nilai-nilai ini masing-masing mewakili kelakuan pengerasan terikan tinggi dan rendah bahan.

Untuk tujuan pegesahan ini, terdapat dua jenis nisbah bidang retak, $a / b$ yang digunakan iaitu, 0.0 dan 1.0 pada koordinat ternormal, $x / h=0.0$ yang dikenakan beban tegangan dan momen lentur. Geometri retak ini dipilih untuk mewakili keadaan retak yang lain kerana keputusan keputusan tersebut adalah hampir sama di antara satu sama lain. Pengesahan $F_{I}$ dalam kajian ini dibandingkan dengan keputusan-keputusan yang diambil daripada Carpinteri \& Vantadori ${ }^{22}$, Shin \& $\mathrm{Cai}^{23}$ dan Carpinteri et al. ${ }^{24}$. Rajah 4.0 menunjukkan perbandingan $F_{I}$ dan didapati bahawa keputusan kajian ini adalah secara relatifnya sama dengan keputusan yang didapati daripada kajian-kajian yang lepas. Oleh itu, model unsur terhingga yang dicadangkan ini digunakan untuk kajian-kajian yang berikutnya 25,26 .

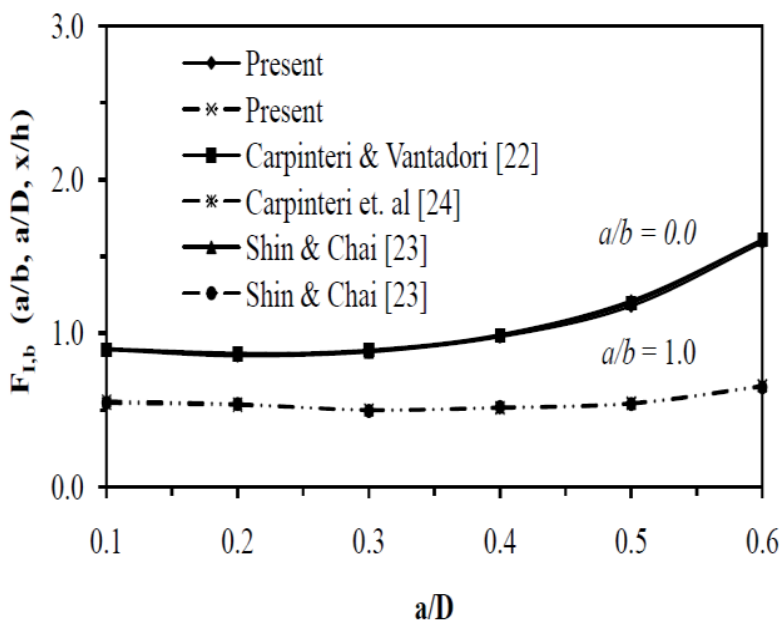

Rajah 4.0 Perbandingan keputusan faktor keamatan tegasan ternormal, $F_{I}$ untuk $a / b=0.0$ dan $a / b=1.0$ kenaan daya tegangan

\subsection{KEPUTUSAN DAN PERBICANGAN}

\subsection{Kamiran-J Daya Tegangan}

Rajah 5.0 menunjukkan hubungan kamiran- $J$ plastik daripada analisis unsur terhingga, $J_{p-F E}$ dan kamiran- $J$ plastik penormalan, $J_{p \text {-normal }}$ untuk kes nisbah bidang retak, $a / b=0.6$ bagi kedalaman relatif retak, $a / D=0.2$ dengan eksponen pengerasan terikan, $n=5$. Untuk geometri retak yang lain, corak hubungan garis lelurus tersebut adalah hampir sama di antara satu sama lain. Kamiran- $J$ beban tinggi sahaja digunakan dalam analisis ini yang mana kamiran- $J$ anjal, $J_{e}$ disingkirkan manakala kamiran- $J$ plastik, $J_{p}$ sahaja yang dipertimbangkan seperti Persamaan (6).

Fungsi- $h$ ini ditentukan dengan mengira kecerunan garis lelurus tersebut untuk tujuh titik di sepanjang retak depan. Ia kemudiannya dinamakan sebagai fungsi- $h_{I, a}$. Kecerunan hubungan garis lelurus ini boleh juga diwakili dengan Persamaan (3.38). Didapati yang kecerunan garis berkenaan semakin mengurang bila kedudukan $x / h$ menghampiri titik paling luar. Tiada perbezaan yang ketara terhadap kecerunan garis untuk titik di kawasan titik terdalam retak $(x / h \leq 0.17)$.

Rajah 6.0 menunjukkan kelakuan fungsi- $h_{I, a}$ terhadap koordinat ternormal, $x / h$ dan pada kedalaman relatif retak, $a / D=$ $0.1,0.2$ dan 0.3. Dalam perbincangan ini, $a / b=0.6,0.8$ dan 1.0 dipilih untuk dibincangkan kerana corak lengkungan adalah tipikal bagi kes retak yang lain kecuali dengan magnitud yang semakin mengecil dengan peningkatan $a / b$. Ini adalah kerana bila $a / b<1.0$ digunakan, retak yang lebih lebar dengan kedalaman yang lebih cetek dapat dihasilkan. Ini sekali gus mengurangkan luas keratan rentas bar secara keseluruhannya. Keadaan ini dapat mengurangkan rintangan bar terhadap beban yang digunakan dan menghasilkan fungsi- $h_{I, a}$ yang lebih tinggi. Keadaan yang berlawanan berlaku bila $a / b>1.0$ digunakan. Fungsi- $h_{I, a}$ yang lebih tinggi dapat dihasilkan jika $n=10$ digunakan. Ini disebabkan ubah bentuk bar dengan mudah berlaku berbanding dengan ubah bentuk bahan yang diandaikan dengan $n=5$.

Rajah 6.0 juga menunjukkan yang fungsi- $h_{I, a}$ memberikan nilai yang maksimum pada titik terdalam retak $(x / h=0.0)$ dan ia menunjukkan arah aliran yang semakin mengurang bila ia menuju ke titik terluar. Seperti yang telah diketahui bahawa kamiran- $J$ bergantung kepada kedalaman relatif retak, $a / D$ yang mana bila $a / D$ semakin meningkat, fungsi- $h_{I, a}$ juga semakin meningkat akibat daripada pengurangan luas keratan rentas bar dan sekali 
gus mengurangkan rintangan bar terhadap beban yang digunakan. Untuk kedalaman retak yang secara relatifnya cetek $(a / D<0.1)$, didapati bahawa perubahan fungsi- $h_{I, a}$ adalah hampir mendatar dengan peningkatan $x / h$. Ini adalah kerana dengan keadaan tersebut, nilai $n$ yang berlainan tidak mempengaruhi kekangan bahan di sekitar retak depan.

Findly et al. ${ }^{2}$ telah menjalankan penyelidikan yang sama tetapi menggunakan pendekatan yang berbeza iaitu dengan menjalankan penyelakuan dan pengiraan fungsi- $h_{I, a}$ secara pendekatan setempat. Tetapi dalam kajian ini, pengiraan fungsi$h_{I, a}$ adalah secara pendekatan global ${ }^{4}$. Dalam kajian itu, penentuan fungsi- $h_{I, a}$ dengan mengambil kira kamiran- $J$ plastik penuh dan hanya fokus kepada $a / D=0.25$ sahaja. Ini adalah kerana, kedalaman tersebut adalah berdasarkan kepada pemerhatian ujikaji. Oleh itu, perbandingan keputusan tidak dapat dijalankan kerana kekangan tersebut.

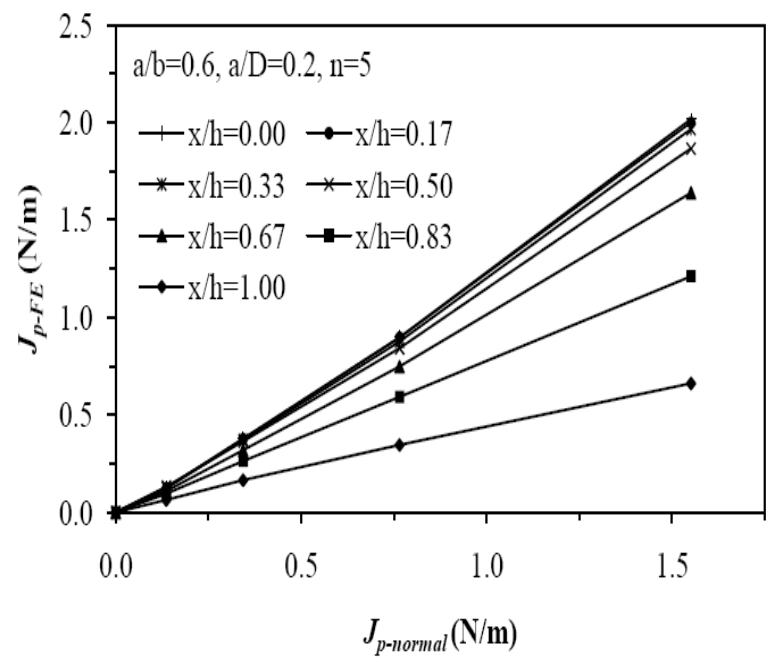

Rajah 5.0 Hubungan di antara $J_{p-F E}$ dan $J_{p-n o r m a l}$ untuk $a / b=0.6, a / D=0.2$ yang dikenakan daya tegangan

\subsection{Kamiran-J Momen Lentur}

Rajah 7.0 menunjukkan hubungan kamiran- $J$ plastik daripada analisis unsur terhingga, $J_{p-F E}$ dan kamiran- $J$ plastik penormalan,

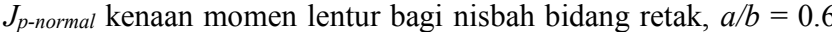
dengan menggunakan eksponen pengerasan terikan, $n=10$ untuk tujuh titik di sepanjang retak depan. Kecerunannya hubungan ini boleh juga diwakili dengan Persamaan (3.39) dan ia dinamakan sebagai fungsi- $h_{l, b}$. Dalam pengiraan tersebut, kamiran- $J$ anjal, $J_{e}$ disingkirkan seperti Persamaan (2.17). Ini adalah kerana fungsi$h_{I, b}$ hanya mewakili kelakuan plastik bahan yang sepenuhnya. Didapati juga yang kecerunan garis lelurus berkenaan semakin mengurang dengan peningkatan $x / h$ dan tiada perbezaan yang ketara terhadap kecerunan tersebut bila $x / h \leq 0.17$ iaitu di kawasan titik terdalam retak.

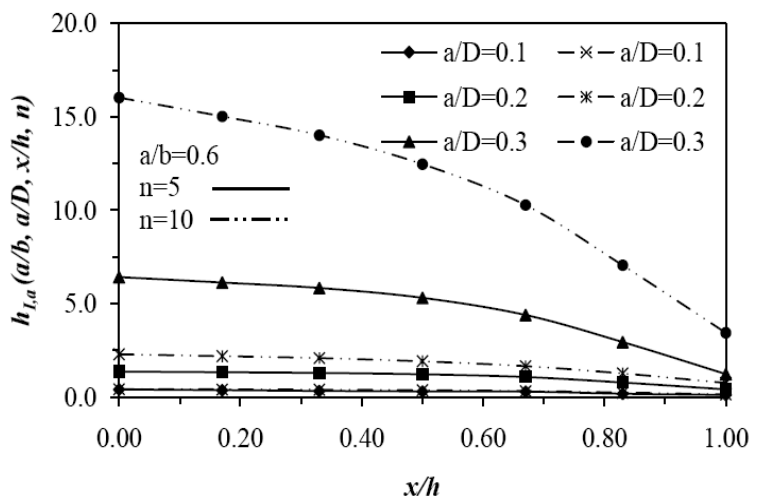

(a)

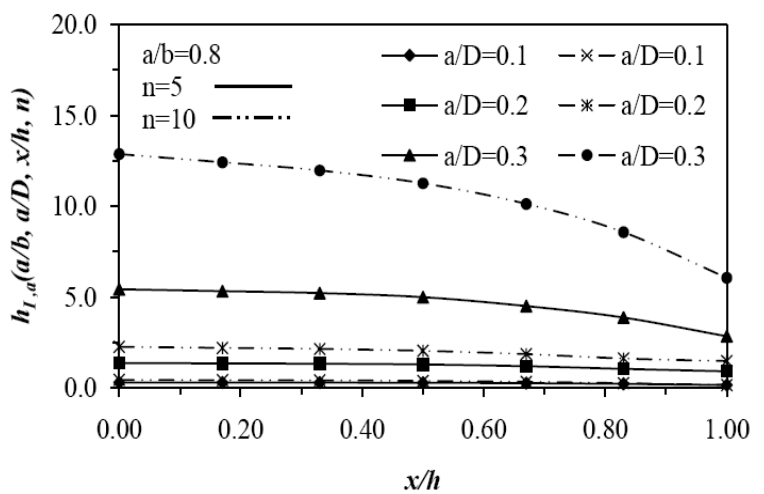

(b)

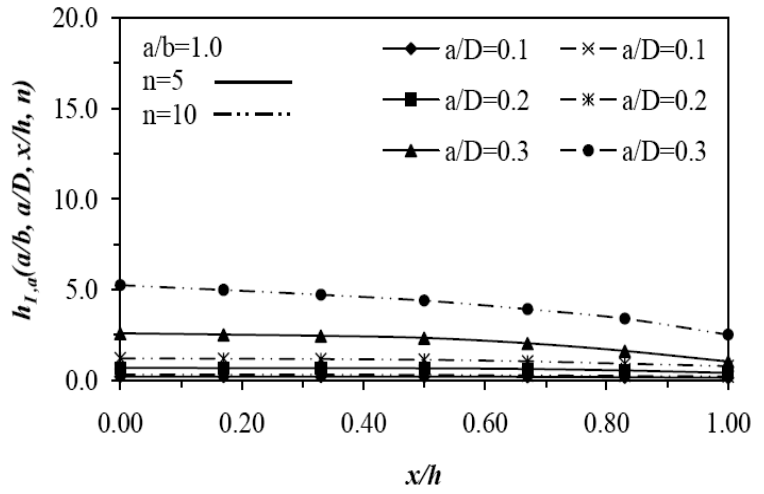

(c)

Rajah 6.0 Kesan fungsi- $h_{I, a}$ terhadap $x / h$, (a) $a / b=0.6$, (b) $a / b=0.8$ dan (c) $a / b=1.0$ kenaan daya tegangan

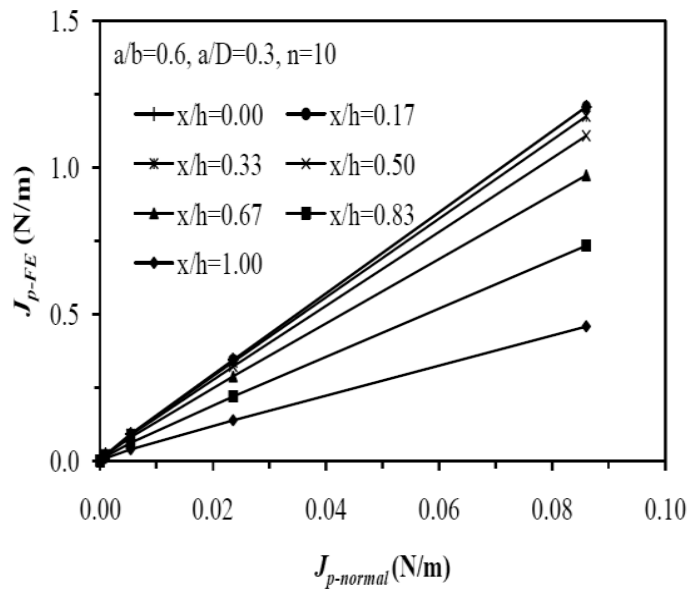

Rajah 7.0 Hubungan di antara $J_{p-F E}$ dan $J_{p \text {-normal }}$ untuk $a / b=0.6, a / D=$ 0.3 dan $n=10$ yang dikenakan momen lentur 


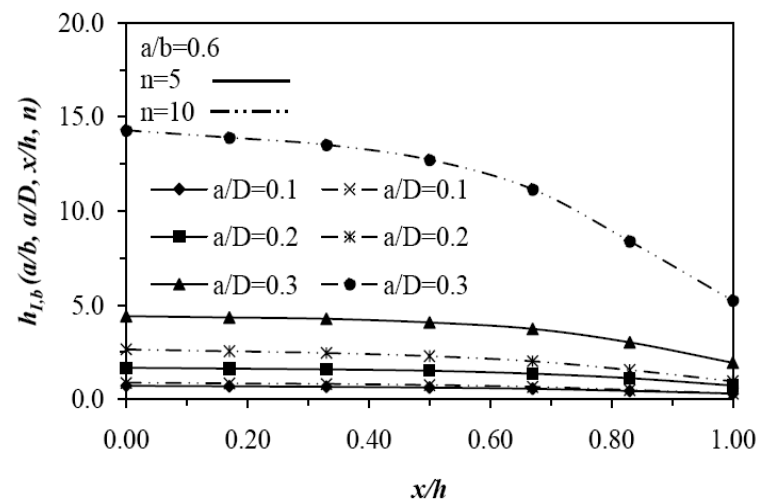

(a)

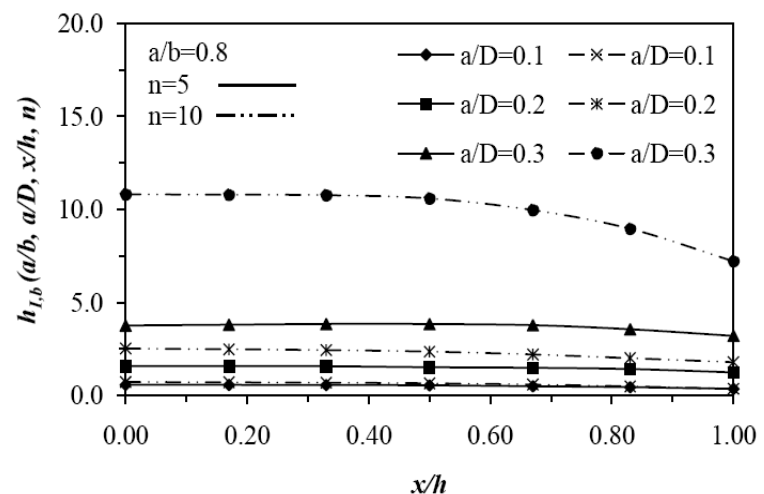

(b)

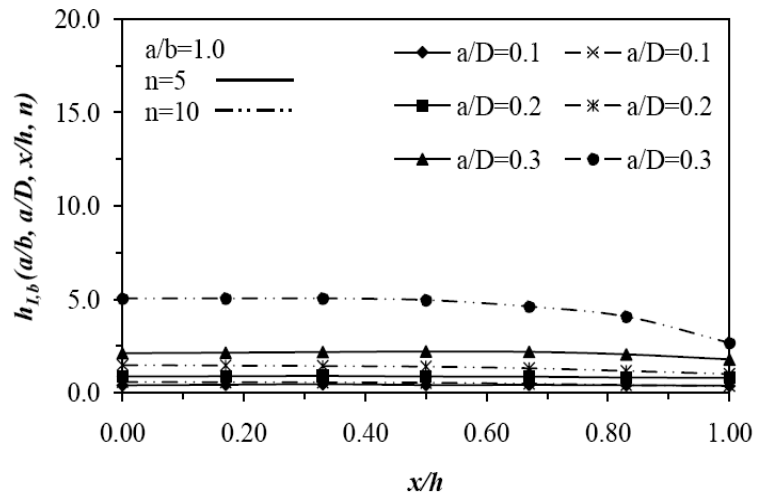

(c)

Rajah 8.0 Kesan fungsi- $h_{I, b}$ terhadap $x / h$, (a) $a / b=0.6$, (b) $a / b=0.8$, (c) $a / b=1.0$ kenaan momen lentur

Rajah 8.0 menunjukan kelakuan fungsi- $h_{I, b}$ melawan koordinat ternormal, $x / h$ bagi $a / b=0.6,0.8$ dan 1.0. Keputusan bagi bentuk retak yang lain tidak dipertimbangkan kerana lengkungan fungsi- $h_{I, b}$ berkenaan adalah tipikal bagi setiap retak tersebut kecuali magnitud lengkungan yang semakin mengurang dengan peningkatan $a / b$. Dengan meningkatkan $a / b$ dapat meluaskan keratan rentas bar dan sekali gus meningkatkan rintangan terhadap beban yang dikenakan. Kelakuan ini seterusnya dapat menghasilkan kamiran- $J$ yang lebih rendah.

Rajah 8.0(a) menunjukkan corak lengkungan bagi $a / b=0.6$ dengan $n=5$ dan 10 sebagai perbandingan untuk $a / D=0.1,0.2$ dan 0.3 . Dengan peningkatan $a / D$ menyebabkan fungsi- $h_{I, b}$ semakin meningkat yang mana peningkatan tersebut menjadi semakin ketara dengan menggunakan $n=10$. Ini adalah kerana bahan tersebut bersifat dengan terikan dengan pengerasan yang rendah. Keadaan in menyumbangkan kepada ubah bentuk bahan yang mudah walaupun beban yang rendah digunakan. Walau bagaimanapun, bagi $a / D=0.1$ memberikan keputusan yang bertepatan di antara satu sama lain walaupun $n$ yang berlainan digunakan yang mana lengkungan tersebut saling bertindihan. Ini menunjukkan bila $a / D=0.1$, nilai $n$ yang berlainan tidak mempengaruhi kelakuan retak bila dikenakan beban. Dengan meningkatkan $a / D$ pengaruh $n$ menjadi semakin ketara. Ini adalah kerana dengan peningkatan tersebut, ubah bentuk bar terhadap beban yang digunakan menjadi semakin ketara. Ditambah lagi dengan penggunaan $n=10$, ubah bentuk menjadi semakin ketara dan sekali gus meningkatkan kamiran- $J$ bagi sesuatu geometri retak di sepanjang retak depan.

Corak lengkungan yang sama dapat diperhatikan untuk $a / b=0.8$ dan 1.0 yang masing-masing seperti dalam Rajah 8.0(b) dan Rajah 8.0(c). Pengurangan fungsi- $h_{I, b}$ dengan meningkatkan $a / b$ adalah disebabkan oleh bentuk retak yang digunakan. Bila $a / b \geq 1.0$ digunakan, lebar retak menjadi semakin mengurang dan pada masa yang sama kedalaman retak menjadi semakin meningkat. Keadaan ini dapat meningkatkan luas keratan rentas bar dan juga meningkatkan rintangan bar terhadap beban yang dikenakan. Keadaan geometri retak ini telah menyebabkan kamiran- $J$ di sepanjang retak depan semakin mengurang dan memberi kesan terhadap pengiraan fungsi- $h_{I, b}$. Perbandingan fungsi- $h_{l, b}$ dengan keputusan daripada kajian yang lepas tidak dapat dijalankan kerana kurang kajian seumpamanya dijalankan terhadap bar ini ${ }^{2}$.

\subsection{Had Beban Momen Lentur}

Had beban ternormal momen lentur, $\xi_{b}$ pada setiap titik di sepanjang retak depan ditentukan dengan menggunakan Persamaan (17) dan had beban tersebut diplotkan melawan beban ternormal, $\sigma_{b} / \sigma_{o}$ seperti dalam Rajah 9.0 dan Rajah 10.0 bagi kes nisbah bidang retak, $a / b=0.8$ masing-masing untuk eksponen pengerasan terikan, $n=5$ dan 10 . Hanya kes $a / b=0.8$ sahaja yang dipertimbangkan kerana kebanyakan corak lengkungan adalah tipikal tetapi dengan magnitud yang berlainan.

Dengan memerhatikan Rajah 9.0, didapati taburan $\xi_{b}$ adalah lebih besar dalam kawasan beban rendah $\left(\sigma_{b} / \sigma_{o}<1.0\right)$ berbanding dengan kawasan beban tinggi $\left(\sigma_{b} / \sigma_{o}>1.0\right)$. Ini adalah kerana pada kawasan beban rendah, kamiran- $J$ anjal mendominasi keadaan yang mana ia memberi kesan yang ketara terhadap pengiraan $\xi_{b}$. Ditambah lagi kamiran- $J$ anjal, $J_{e}$ kurang relevan dalam penentuan had beban. Dengan kehadiran $J_{e}$ dalam pengiraan tersebut dapat menghasilkan perselisihan lengkungan yang ketara di sepanjang retak depan. Walau bagaimanapun, dengan peningkatan beban $\left(\sigma_{b} / \sigma_{o}>1.0\right)$, kesemua lengkungan had beban merapati di antara satu sama lain. Ini menunjukkan hanya kamiran- $J$ plastik, $J_{p}$ sahaja yang sesuai atau relevan dalam penentuan had beban. Ini juga adalah bertepatan dengan Persamaan (7) yang mengandungi parameter $L r$ yang merupakan satu parameter plastik yang sepenuhnya.

Manakala, Rajah 10.0 menunjukkan $\xi_{b}$ untuk kes $n=10$. Kelakuan lengkungan ini adalah hampir sama dengan lengkungan yang menggunakan $n=5$. Walau bagaimanapun, lengkungan tersebut adalah lebih tinggi berbanding dengan lengkungan yang menggunakan $n$ yang lebih rendah yang disebabkan oleh keupayaan ubah bentuk bahan yang berbeza. Kelakuan $\xi_{b}$ dalam Rajah 9.0 dan Rajah 10.0 mungkin boleh diterangkan secara terperinci dengan memerhatikan corak nisbah kamiran- $J, J / J_{e}$ di sepanjang retak depan yang diplotkan melawan koordinat ternormal, $x / h$. Dengan menggantikan Persamaan (4) dan Persamaan (6) ke dalam Persamaan (5) untuk menjadi seperti Persamaan (19) yang mana $J / J_{e}$ diterbitkan fungsi kepada geometri bar, beban dan sifat-sifat bahan seperti berikut 


$$
\frac{J\left(\frac{x}{h}\right)}{J_{e}\left(\frac{x}{h}\right)}=1+\frac{9 \pi \alpha\left(\frac{3 \pi}{16} \frac{\sigma_{b}}{\sigma_{o}}\right)^{n-1}}{128\left(\frac{a}{R}\right)\left(1-v^{2}\right)}\left(\frac{h_{I, b}\left(\frac{x}{h}\right)}{F_{I, b}^{2}\left(\frac{x}{h}\right)}\right)
$$

yang mana, $J=J_{e}+J_{p}$. Dalam Persamaan (19) didapati bahawa hanya terdapat parameter $x / h$ yang berubah dan parameter yang lain diandaikan malar.

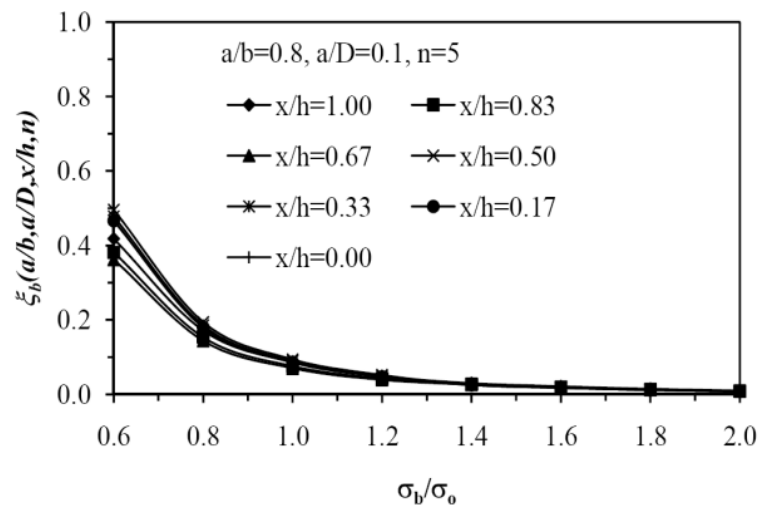

(a)

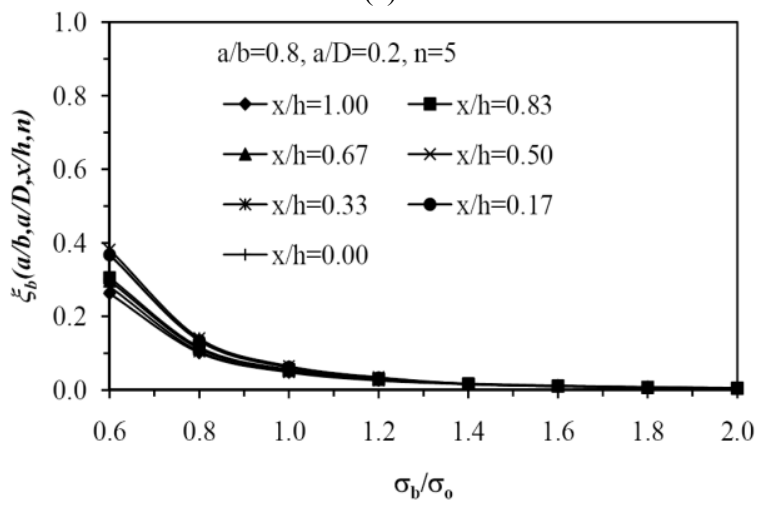

(b)

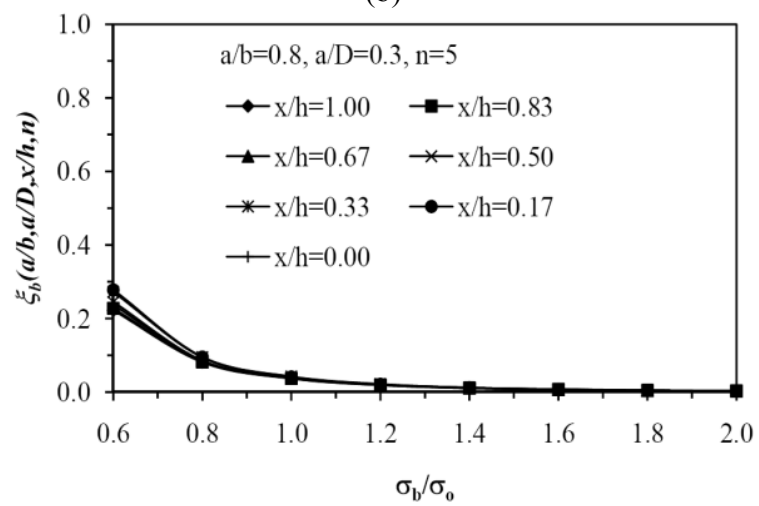

(c)

Rajah 9.0 Kelakuan $\xi_{b}$ terhadap $\sigma_{b} / \sigma_{o}$ untuk $a / b=0.8$ (a) $a / D=0.1$, (b) $a / D=0.2$ dan (c) $a / D=0.3$ bagi $n=5$

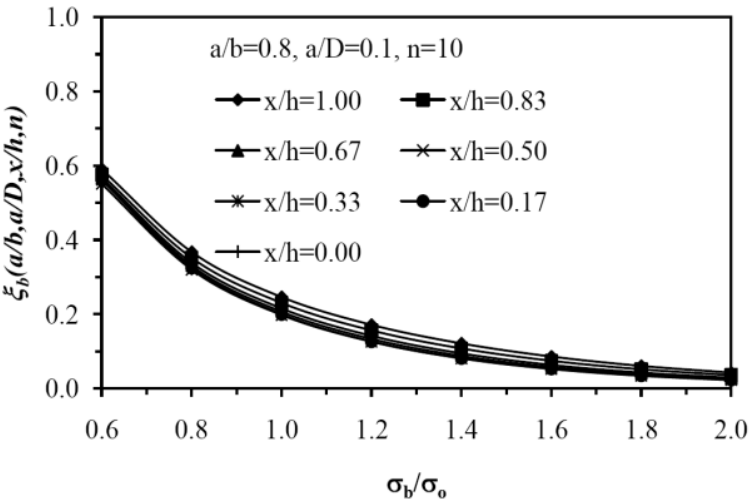

(a)

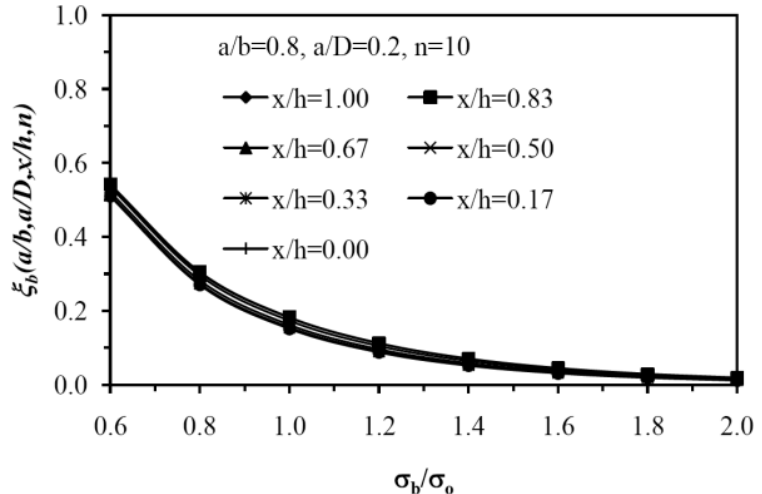

(b)

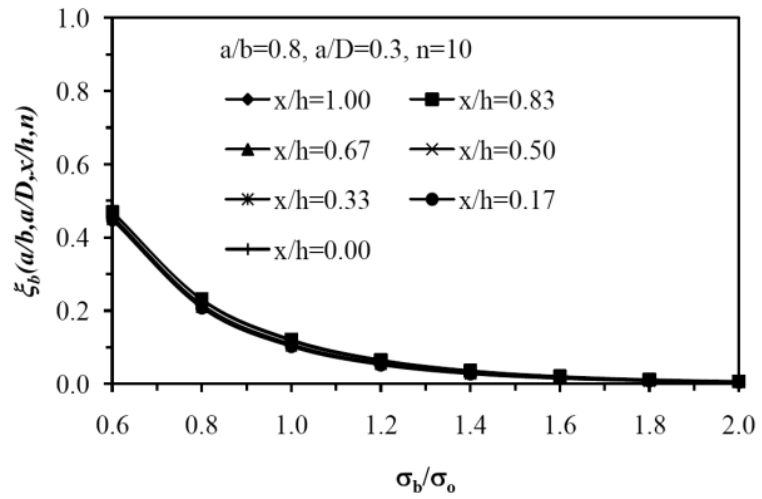

(c)

Rajah 10.0 Kelakuan $\xi_{b}$ terhadap $\sigma_{b} / \sigma_{o}$ untuk $a / b=0.8$ (a) $a / D=0.1$, (b) $a / D=0.2$ dan (c) $a / D=0.3$ bagi $n=10$

Oleh itu, $J / J_{e}$ ditentukan hanya dengan menggunakan parameter $h_{I, b} / F_{I, b}^{2}$ untuk pelbagai bentuk retak yang dipertimbangkan. Kelakuan $h_{I, b} / F^{2}{ }_{I, b}$ terhadap $x / h$ yang menggunakan eksponen pengerasan terikan, $n=5$ dan 10 adalah masing-masing seperti Rajah 11.0 dan Rajah 12.0. Daripada Rajah 11.0(a), didapati untuk kedalaman relatif retak, $a / D=0.1$ dalam kawasan $x / h<0.6$, parameter $h_{I, b} / F_{I, b}^{2}$ adalah hampir mendatar atau tetap di sepanjang retak depan. Oleh itu, kamiran- $J$ boleh dianggarkan dengan menggunakan kaedah tegasan rujukan yang menggunakan hanya satu had beban dalam kawasan tersebut. 


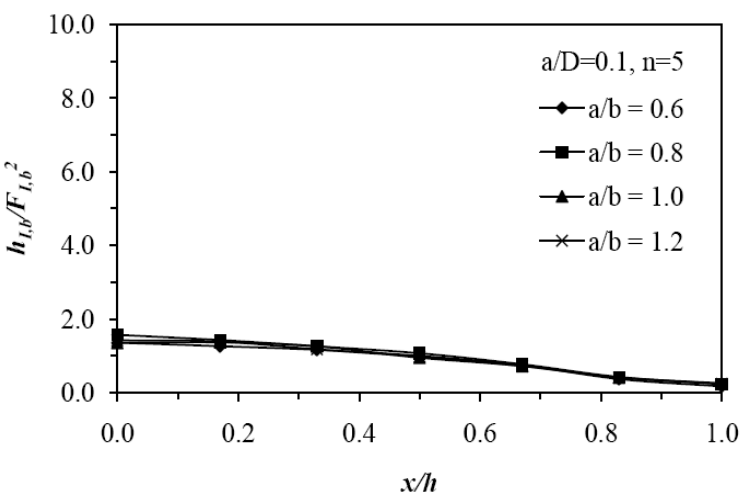

(a)

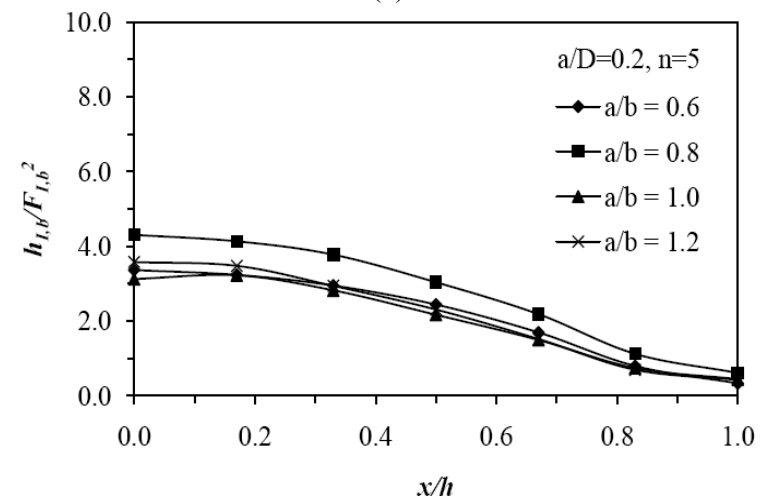

(b)

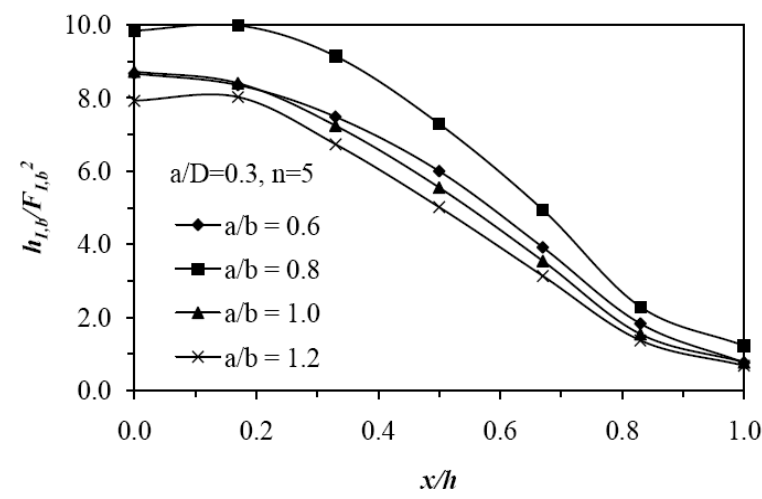

(c)

Rajah 11.0 Kelakuan $h_{I, b} / F_{I, b}^{2}$ terhadap $x / h$ untuk, (a) $a / D=0.1$, (b) $a / D=$ 0.2 dan (c) $a / D=0.3$ untuk $n=5$

Dengan meningkatkan $a / D$ didapati kecerunan lengkungan $h_{l, b} / F^{2}{ }_{l, b}$ menjadi semakin meningkat. Didapati juga kesemua lengkungan $h_{I, b} / F^{2}{ }_{I, b}$ dicerap menumpu kepada satu titik yang terletak di titik paling bar. Untuk $a / D \geq 0.2$, penggunaan satu had beban tidak dapat digunakan untuk meramal kamiran- $J$ di sepanjang retak depan. Ini adalah kerana lengkungan $h_{I, b} / F^{2}{ }_{I, b}$ adalah tidak mendatar atau tetap seperti Rajah 11.0(b) dan Rajah $11.0(\mathrm{c})$. Oleh yang demikian, had beban berlainan perlu digunakan untuk menganggar kamiran- $J$ pada titik yang berlainan disepanjang retak depan.

Kelakuan $h_{I, b} / F^{2}{ }_{I, b}$ yang sama dapat diperhatikan jika $n=10$ digunakan seperti dalam Rajah 12.0. Walau bagaimanapun, terdapat peningkatan taburan magnitud $h_{I, b} / F_{I, b}^{2}$ berbanding dengan jika $n=5$ digunakan. Dengan peningkatan $a / D$, parameter $h_{I, b} / F^{2}{ }_{I, b}$ menunjukkan perbezaan yang ketara di sepanjang hujung retak seperti dalam Rajah 12.0(b) dan Rajah 12.0(c) berbanding dengan Rajah 12.0(a). Ini menunjukkan adalah menjadi kesukaran untuk menganggar kamiran- $J$ pada kedudukkan tertentu di sepanjang hujung retak dengan menggunakan satu had beban sahaja. Keupayaan proses penganggaran kamiran- $J$ diperhatikan terhad pada kedalaman retak tertentu $(a / D \leq 0.1)$. Walau bagaimanapun, penganggaran tersebut masih boleh dijalankan bagi $a / D>0.1$ tetapi dalam kawasan $x / h<0.2$ sahaja kerana lengkungan yang berada dalam kawasan $x / h>0.2$ menunjukkan pengurangan yang agak ketara.

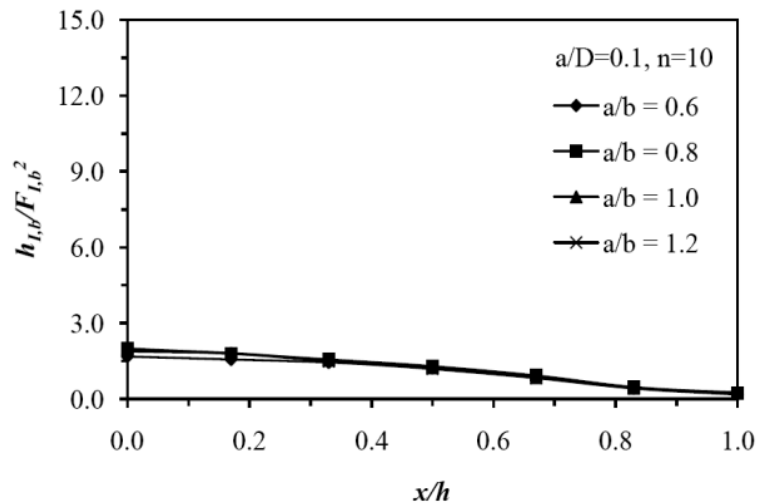

(a)

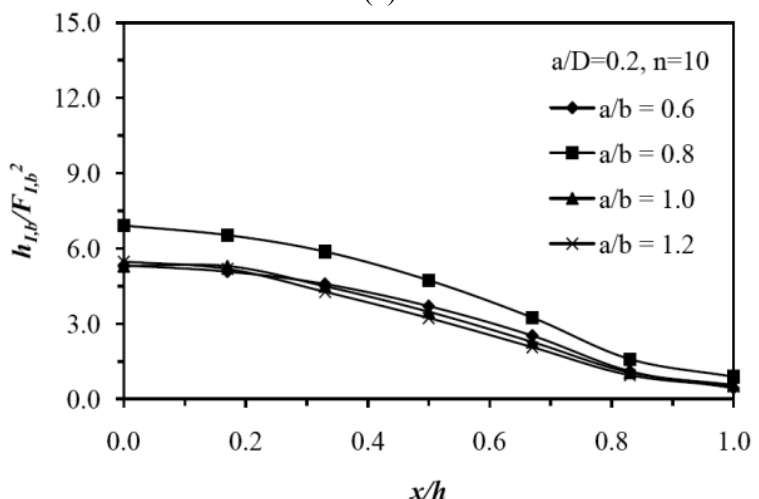

(b)

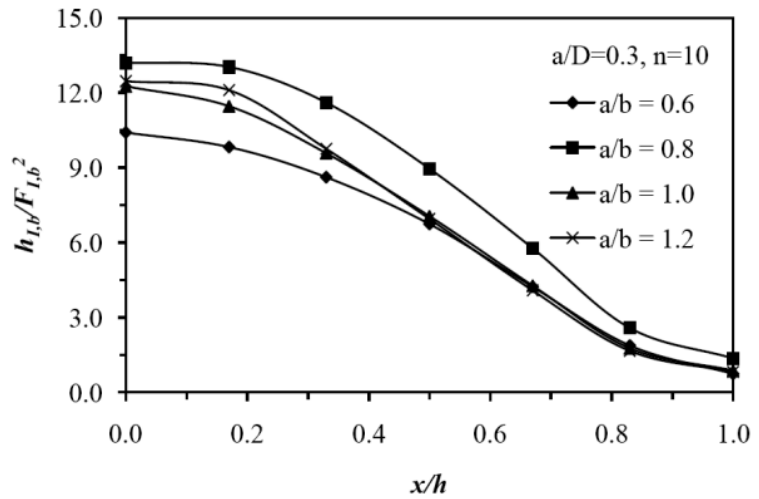

(c)

Rajah 12.0 Kelakuan $h_{I, b} / F_{I, b}^{2}$ terhadap $x / h$ untuk, (a) $a / D=0.1$, (b) $a / D$ $=0.2$ dan (c) $a / D=0.3$ untuk $n=10$

\subsection{Had Beban Daya Tegangan}

Persamaan (17) digunakan untuk mengira had beban ternormal daya tegangan, $\xi_{a}$. Rajah 13.0 menunjukkan $\xi_{a}$ yang menggunakan eksponen pengerasan terikan, $n=5$ untuk nisbah bidang retak, $a / b=0.6$ yang diplotkan melawan beban ternormal, $\sigma_{a} / \sigma_{o}$. Disebabkan corak dan taburan $\xi_{a}$ ini adalah tipikal, hanya $a / b=0.6$ sahaja yang dipertimbangkan untuk 
perbincangan. Lengkungan $\xi_{a}$ ini boleh dibahagikan secara umumnya kepada dua kawasan iaitu $\sigma_{a} / \sigma_{o}<1.0$ (kawasan beban rendah) dan $\sigma_{a} / \sigma_{o}>1.0$ (kawasan beban tinggi).

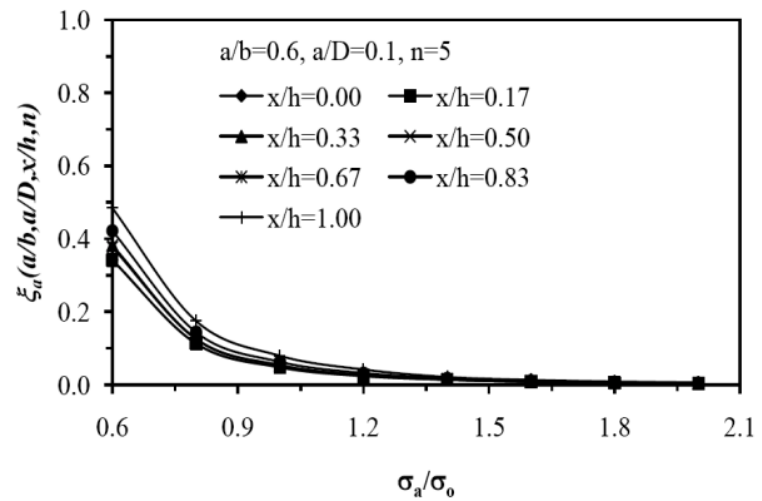

(a)

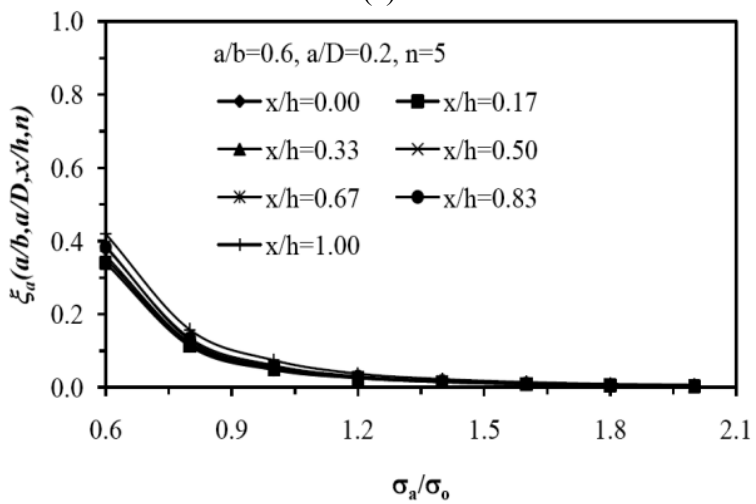

(b)

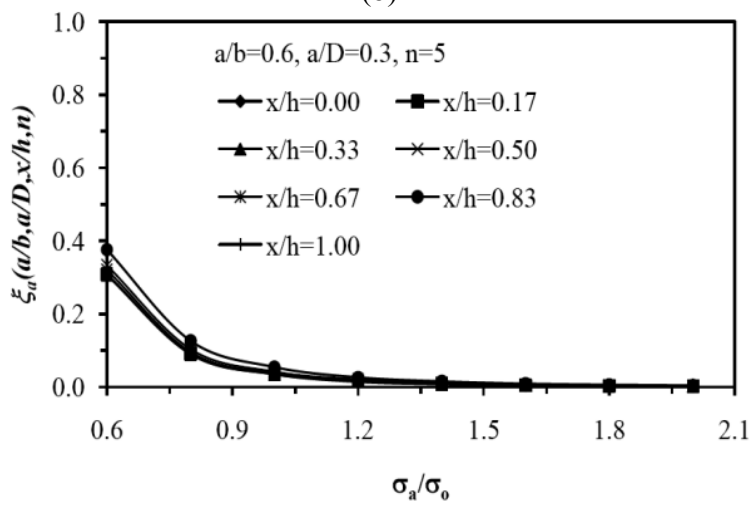

(c)

Rajah 13.0 Kelakuan $\xi_{a}$ terhadap $\sigma_{a} / \sigma_{o}$ untuk $a / b=0.6$ (a) $a / D=0.1$, (b) $a / D=0.2$ dan (c) $a / D=0.3$ bagi $n=5$

Dalam kawasan $\sigma_{a} / \sigma_{o}<1.0$, kelihatan $\xi_{a}$ pada setiap titik di sepanjang retak depan adalah berjauhan di antara satu sama lain. Ini adalah kerana dalam mengira had beban, kamiran- $J$ anjal tidak sesuai dalam pengiraan tersebut yang mana ia menyumbang kepada taburan $\xi_{a}$ yang tinggi secara relatifnya berbanding dengan kawasan $\sigma_{a} / \sigma_{o}>1.0$. Oleh itu, dalam pengiraan had beban pengaruh kamiran- $J$ anjal disingkirkan untuk mengelakan kesan tersebut melalui Persamaan (5).

Manakala, $\xi_{a}$ pada titik terluar pada hujung retak $(x / h=1.0)$ terletak berasingan (satah tegasan) daripada kelompok $\xi_{a}$ yang lain (satah terikan) disebabkan oleh perbezaan kekangan di sekeliling titik yang dipertimbangkan di sepanjang retak depan. Dengan meningkatkan kedalaman relatif retak, $a / D$, had beban bagi bar ini semakin mengurang. Kelakuan ini adalah disebabkan oleh pengurangan rintangan bar terhadap beban atau pengurangan luas keratan rentas bar. Ini sekali gus meningkatkan kamiran- $J$ di sepanjang retak depan. Oleh itu, pengaruh kamiran- $J$ plastik semakin meningkat. Ini ditunjukkan oleh pengecilan taburan $\xi_{a}$ seperti dalam Rajah 13.0(b) dan Rajah 13.0(c) berbanding dengan Rajah 13.0(a).

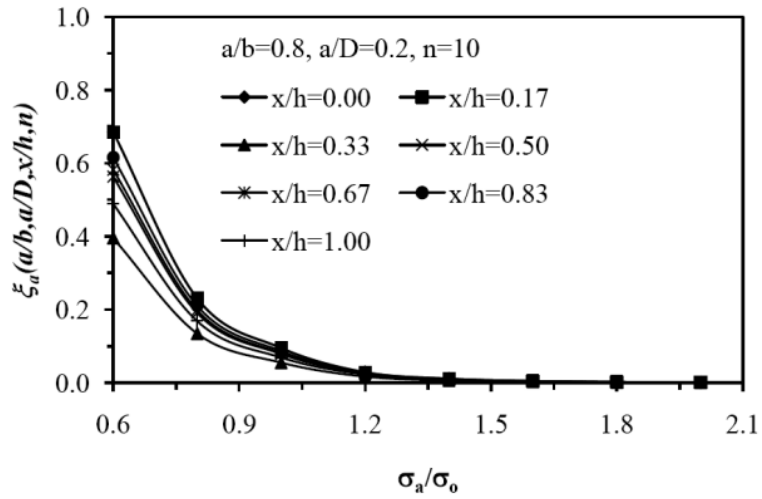

(a)

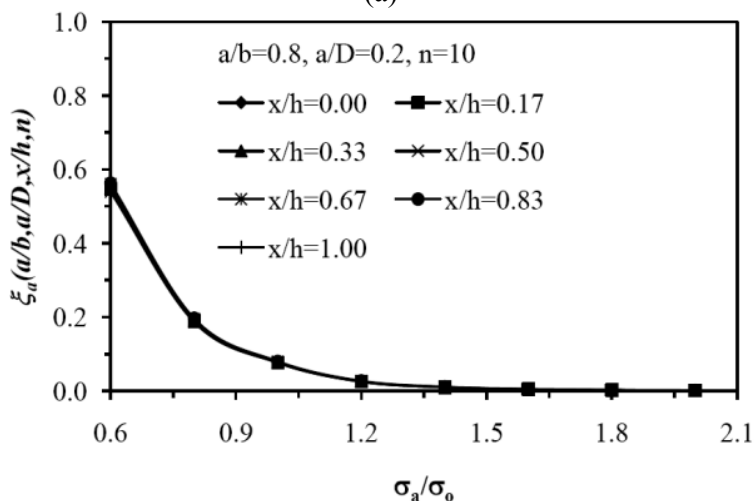

(b)

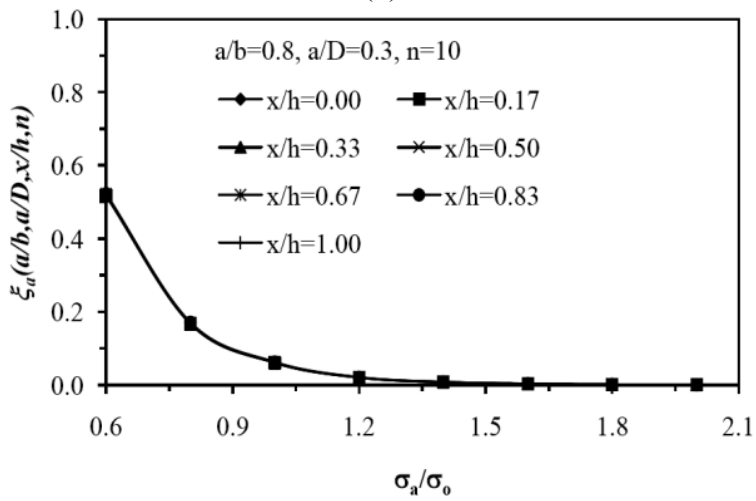

(c)

Rajah 14.0 Kelakuan $\xi_{a}$ terhadap $\sigma_{a} / \sigma_{o}$ untuk $a / b=0.6$ (a) $a / D=0.1$, (b) $a / D=0.2$ dan (c) $a / D=0.3$ bagi $n=10$

Kelakuan lengkungan $\xi_{a}$ yang tipikal juga dapat dicerap yang menggunakan $n=10$ seperti dalam Rajah 14.0 yang mana $a / b=0.6$ digunakan untuk perbincangan. Taburan $\xi_{a}$ yang sekata dapat diperhatikan di sepanjang retak depan kecuali untuk $a / D=0.1$. Ini adalah kerana bila $a / D=0.1$, ia masih lagi mempunyai ketahanan terhadap beban yang dikenakan. Oleh itu, pengaruh kamiran- $J$ anjal mendominasi di sepanjang retak depan dan ini menghasilkan taburan lengkungan $\xi_{a}$ yang tinggi. 
Manakala, perkara sebaliknya berlaku jika $a / D>0.1$ yang mana pengaruh kamiran- $J$ plastik menjadi semakin ketara. Had beban ternormal, $\xi_{a}$ bagi $n=10$ adalah lebih tinggi berbanding dengan $\xi_{a}$ yang menggunakan $n=5$. Ini adalah kerana jika sesuatu bahan yang menggunakan $n=10$, bahan tersebut berkelakuan dengan berterikan dengan pengerasan yang rendah. Oleh itu, beban yang dikenakan ke atas bar dengan mudah dapat mengubah bentuk dan seterusnya menghasilkan had beban yang tinggi.

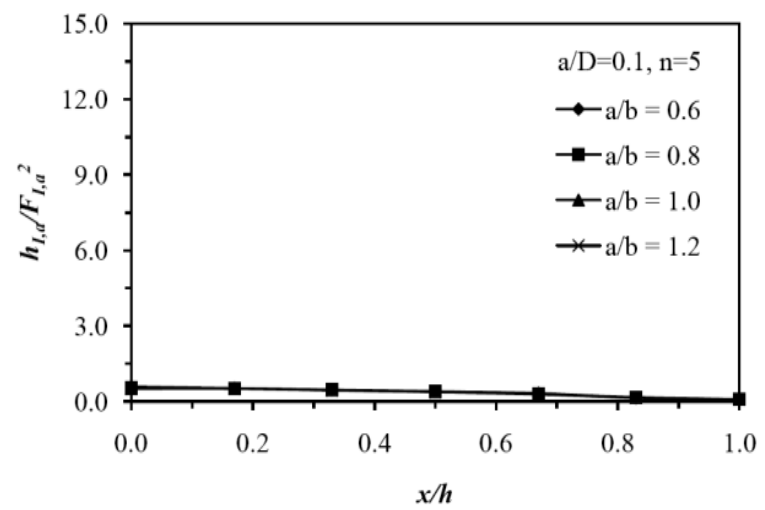

(a)

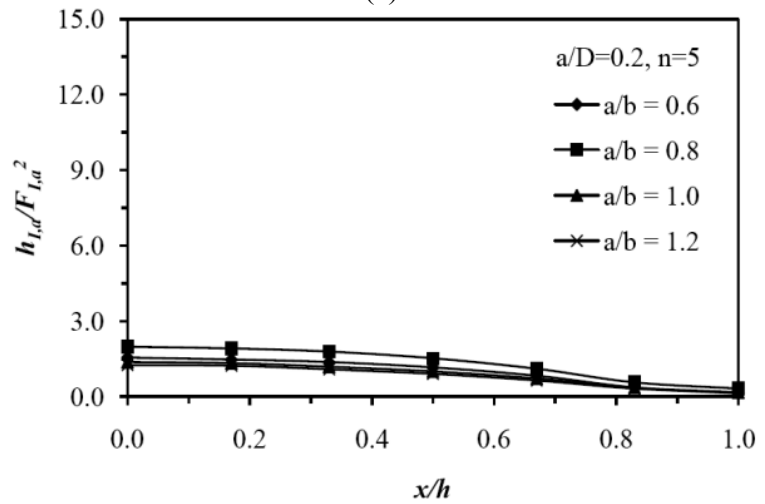

(b)

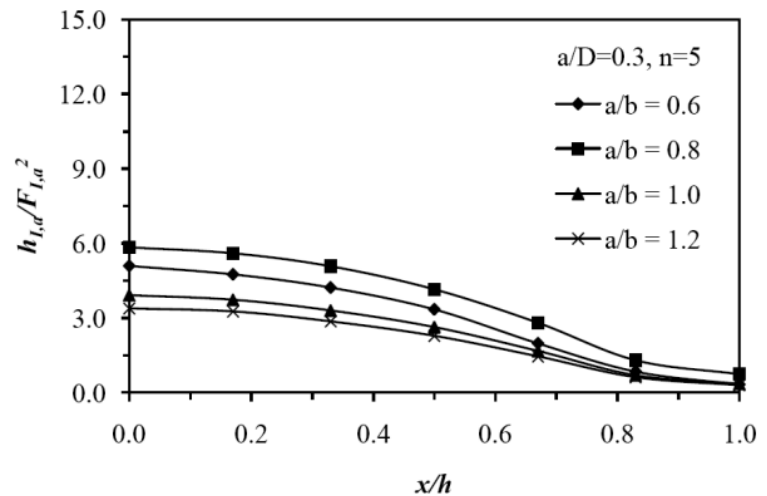

(c)

Rajah 15.0 Kelakuan $h_{I, a} / F_{I, a}^{2}$ terhadap $x / h$ untuk, (a) $a / D=0.1$, (b) $a / D=$ 0.2 dan (c) $a / D=0.3$ untuk $n=5$

Kelakuan $\xi_{a}$ dalam Rajah 13.0 dan Rajah 14.0 mungkin boleh digambarkan dengan memerhatikan corak nisbah kamiran$J, J / J_{e}$ di sepanjang retak depan. Gantikan Persamaan (2.16) dan Persamaan (2.18) ke dalam Persamaan (2.17) untuk menjadi seperti Persamaan (5.2). Ia diterbitkan fungsi kepada geometri bar, beban dan sifat-sifat bahan seperti berikut

$$
\frac{J\left(\frac{x}{h}\right)}{J_{e}\left(\frac{x}{h}\right)}=1+\frac{2 \alpha\left(\frac{\sigma_{a}}{\sigma_{o}}\right)^{n-1}}{\pi\left(\frac{a}{R}\right)\left(1-v^{2}\right)}\left(\frac{h_{I, a}\left(\frac{x}{h}\right)}{F_{I, a}^{2}\left(\frac{x}{h}\right)}\right)
$$

yang mana, $J=J_{e}+J_{p}$ dan didapati hanya parameter $x / h$ yang berubah dan parameter yang lain diandaikan tetap. Oleh itu, $J / J_{e}$ ditentukan hanya oleh $h_{I, a} / F_{I, a}^{2}$ untuk pelbagai bentuk retak yang dipertimbangkan. Kelakuan $h_{I, a} / F_{I, a}^{2}$ terhadap $x / h$ yang menggunakan $n=5$ dan 10 adalah masing-masing seperti dalam Rajah 15.0 dan Rajah 16.0.

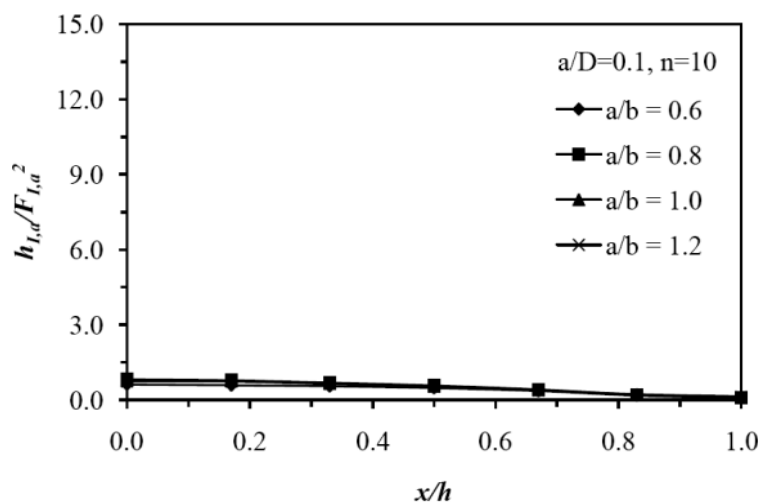

(a)

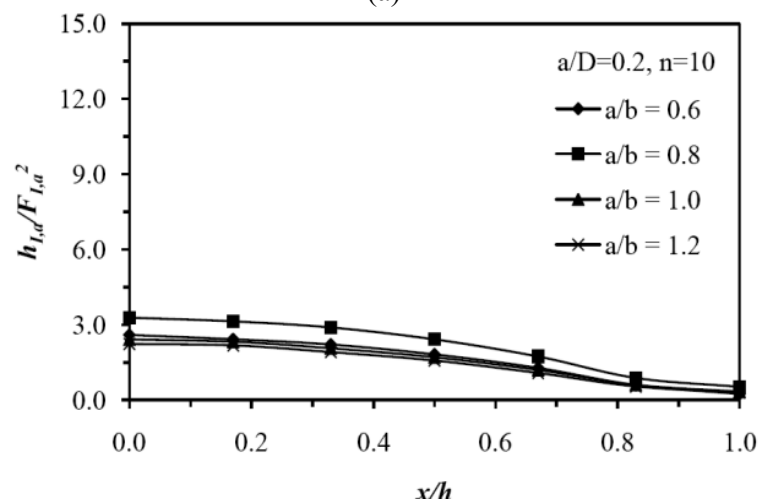

(b)

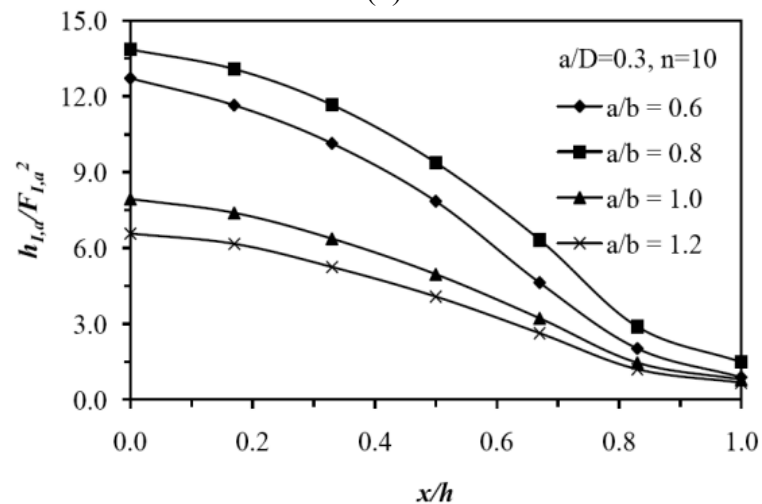

(c)

Rajah 16.0 Kelakuan $h_{I, a} / F_{I, a}^{2}$ terhadap $x / h$ untuk, (a) $a / D=0.1$, (b) $a / D=$ 0.2 dan (c) $a / D=0.3$ untuk $n=10$

Dalam julat $x / h \leq 0.8$, kelakuan $h_{I, a} / F^{2}{ }_{I, a}$ adalah hampir mendatar di sepanjang retak depan seperti dalam Rajah 15.0(a). Ini menunjukkan yang satu had beban sahaja boleh digunakan untuk menganggar kamiran- $J$ untuk semua $a / b$ yang 
dipertimbangkan pada $a / D=0.1$. Dalam kawasan $x / h>0.8$ pula menunjukkan sedikit pengurangan sebelum semua lengkungan terlibat dilihat menumpu pada $x / h=1.0$. Dengan peningkatan $a / D$ sebanyak 0.1 seperti dalam Rajah 15.0(b) dengan jelasnya menunjukkan corak yang sama seperti dalam Rajah 15.0(a). Kecuali lengkungan $h_{I, a} / F_{I, a}^{2}$ adalah lebih tinggi. Ia juga menunjukkan yang keadaan lengkungan yang mendatar semakin mengurang dalam kawasan $x / h<0.5$ berbanding dengan $x / h<0.85$ bagi $a / D=0.1$.

Ini bermakna yang kebolehan Persamaan (20) dalam menganggarkan kamiran- $J$ di sepanjang retak depan semakin berkurangan dengan meningkatkan $a / D$. Oleh itu had beban yang berlainan perlu digunakan untuk menentukan kamiran- $J$ dalam kawasan $x / h>0.5$ kerana lengkungan dalam kawasan tersebut adalah tidak mendatar. Dalam julat $x / h>0.5$ juga memaparkan kelakuan pengurangan $h_{I, a} / F_{I, a}^{2}$ yang mana kesemua lengkungan terbabit menumpu kepada satu titik pada $x / h=1.0$. Keadaan ini menunjukkan yang pada titik tersebut, kamiran- $J$ mempunyai masalah dari segi ketunggalan.

Rajah 15.0(c) menunjukkan lengkungan $h_{I, a} / F^{2}{ }_{I, a}$ untuk $a / D=0.3$. Dengan meningkatkan $a / D$ telah menyebabkan keadaan mendatar bagi lengkungan $h_{I, a} / F_{I, a}^{2}$ semakin mengurang sehingga $x / h \leq 0.2$. Dengan pengurangan tersebut bermaksud menjadi kesukaran untuk menganggar kamiran- $J$ di sepanjang retak depan. Ia bermakna had beban yang berlainan perlu digunakan untuk menganggar kamiran- $J$ pada titik yang berlainan. Manakala, Rajah 16.0 pula menunjukkan kelakuan lengkungan yang hampir sama dengan Rajah 15.0 kecuali magnitud lengkungan $h_{I, a} / F_{I, a}^{2}$ adalah lebih besar terutama sekali untuk $a / D \geq 0.3$

Perbezaan ini adalah disebabkan oleh bahan tersebut menggunakan $n=10$ yang bersifat pengerasan terikan rendah. Oleh yang demikian, walaupun beban yang rendah dikenakan, ia dapat menghasilkan kamiran- $J$ yang tinggi kerana kebolehan ubah bentuk bahan yang tinggi. Keadaan ini menjadi lebih ketara dengan peningkatan kedalaman retak seperti Rajah 16.0(c) yang secara relatifnya lebih tinggi berbanding dengan $a / D \leq 0.2$ seperti Rajah 16.0(a) dan Rajah 16.0(b).

\subsection{KESIMPULAN}

Dalam kajian ini, model unsur terhingga untuk retak permukaan pada bar silinder dibangunkan dengan menggunakan perisian ANSYS. Kemudian, kamiran- $J$ ditentukan disepanjang retak depan untuk bar yang dikenakan beban ragam I. Pada masa yang sama juga, model matematik untuk penganggaran kamiran- $J$ juga dibangunkan dengan menggunakan pendekatan tegasan rujuk dengan mengabungkannya dengan had beban yang dibangunkan. Dalam mengkaji hubungan di antara kamiran- $J$ dan had beban yang telah dibangunkan dan ia digabungkan dengan kaedah pendekatan tegasan rujukan. Kemudian, kamiran- $J$ yang dianggarkan dengan persamaan matematik ini diplotkan melawan koordinat di sepanjang retak depan. Didapati daripada hasil plotan tersebut menunjukkan kelakuan lengkungan yang sama jika jenis beban yang berlainan digunakan yang mana kebolehanggaran kamiran- $J$ semakin mengurang dengan meningkatkan kedalaman relatif retak. Kebolehanggaran ini dicerap yang mana keadaan lengkungan tersebut adalah mendatar di sepanjang retak depan. Ia menunjukan lengkungan yang mendatar ini bermaksud hanya satu had beban sahaja yang diperlukan dan berupaya untuk menganggarkan kamiran-J. Jika lengkungan dengan kecerunan dihasilkan, had beban yang berlainan adalah diperlukan untuk menganggarkan kamiran- $J$ pada titik yang berlainan di sepanjang retak depan. Secara kesimpulannya, penggunaan model matematik yang dibangunkan dalam menganggarkan kamiran-J disepanjang retak depan adalah terhad kepada retak yang cetek sahaja iaitu $a / D \leq 0.2$. Walau bagaimanapun untuk kedalaman retak $a / D>0.2$, kebolehanggaran tersebut hanya terhad dalam kawasan titik retak terdalam sahaja. Cadangan untuk penyelidikan yang akan datang adalah lebih fokus kepada membangunkan had beban yang diandaikan bersifat plastik sepenuhnya. Dalam kajian ini, had beban yang dibangunkan adalah berdasarkan andaian yang bahan yang digunakan adalah bersifat anjal-plastik sempurna.

\section{Penghargaan}

Pengarang mengucapkan terima kasih kepada Universiti Tun Hussein Onn Malaysia (UTHM) kerana telah menyokong penyelidikan ini.

Rujukan

[1] Murakami, Y. \& Tsuru, H. 1987. Stress Intensity Factors Handbook Oxford: Pergamon Press. 657-658.

[2] Findley, K. O., Koh S.W. \& Saxena, A. 2007. Int. J. of Fatigue. 29: 822828.

[3] Laham, S. A. 1998. Stress Intensity Factor and Limit Load Handbook. British Energy Generation. SINTAP Issue 2

[4] Lei, Y. 2007. Int. J. of Pressure Vessels and Piping. 84: 545-559.

[5] Lei, Y. 2008. Int. J. of Pressure Vessels and Piping. 8: 825-850.

[6] Kim, Y. J. \& Shim, D. J. 2005. Int. J. of Pressure Vessels and Piping. 82: 687-699.

[7] Lei, Y. \& Budden, P. J. 2004a. Int. J. of Pressure Vessels and Piping. 81: 589-597.

[8] Lei, Y. \& Budden, P.J. 2004b. J. of Strain Analysis. 39(6): 673-683.

[9] Ruggieri, C. 2011. Procedia Engineering. 10: 1703-1708.

[10] Lei, Y. \& Fox, M. J. H. 2011. Int. J. of Pressure Vessels and Piping. 88(8-9): 348-355.

[11] Rice, J. R. 1968. J. of Applied Mechanics. 35: 379-386.

[12] Rahman, S. 2001. Engineering Fracture Mechanics. 68: 107-125.

[13] Kumar, V., German, M. D. \& Shih, C. F. 1981. An Engineering Approach for Elastic-Plastic Fracture Analysis. EPRI NP-1931, Project 1237.

[14] Yagawa, G., Kitajima, Y. \& Ueda, H. 1993. Int. J. of Pressure Vessels and Piping. 53: 457-510.

[15] Lei, Y. 2004a. Int. J. of Pressure Vessels Piping. 81(1): 31-41.

[16] Lei, Y. 2004b. Int. J. of Pressure Vessels and Piping. 81(1): 31-41.

[17] Lei, Y. 2004c. Int. J. of Pressure Vessels and Piping. 81(1): 21-30.

[18] Ainsworth, R. A. 1984. Engineering Fracture Mechanics. 19: 633-42.

[19] Miller, A. G. 1988. Int. J. of Pressure Vessels and Piping. 32: 191-327.

[20] Dowling, N. E. 2006. Mechanical Behaviour of Materials: Engineering Methods for Deformation, Fracture and Fatigue. Ed. ke-3. New Jersey: Pearson Prentice Hall

[21] Cai, C. Q. \& Shin, C. S. 2004. Nuclear Engineering and Design 227(3): $355-358$

[22] Carpinteri, A. \& Vantadori, S. 2009. Int. J. of Fatigue. 31:759-765.

[23] Shin, C. S \& Cai, C. Q. 2004. Int. J. of Fracture. 129: 239-264.

[24] Carpinteri, A., Brighenti, R. \& Vantadori, S. 2006. Int. J. of Fatigue. 28: 251-260.

[25] Ismail, A. E., Ariffin, A. K., Abdullah, S. \& Ghazali, M. J. 2012. Meccanica. 47: 1141-1156.

[26] Ismail, A. E., Ariffin, A. K., Abdullah, S. \& Ghazali, M. J. 2012. Indian J. of Engineering Materials and Science. 19(1): 5-16. 